\title{
Synthesis, Spectroscopic Studies and X-Ray Diffraction of Heptacoordinated Mn(II) and Co(II) Complexes with Ligands Derived from Carbonohydrazide
}

\author{
Thierno Moussa Seck , Adama Sy², Djiby Lo1, Papa Aly Gaye3 ${ }^{3}$, Mohamed Lamine Sall1, \\ Ousmane Diouf ${ }^{1}$, Mahy Diaw ${ }^{1}$, Mohamed Gaye ${ }^{1 *}$ (1) \\ ${ }^{1}$ Department of Chemistry, University Cheikh Anta Diop, Dakar, Senegal \\ ${ }^{2}$ Department of Chemistry, University Gaston Berger, Saint-Louis, Senegal \\ ${ }^{3}$ Department of Chemistry, University Assane SECK, Ziguinchor, Senegal \\ Email: *mohamedl.gaye@ucad.edu.sn
}

How to cite this paper: Seck, T.M., Sy, A., Lo, D., Gaye, P.A., Sall, M.L., Diouf, O., Diaw, M. and Gaye, M. (2019) Synthesis, Spectroscopic Studies and X-Ray Diffraction of Heptacoordinated $\mathrm{Mn}$ (II) and $\mathrm{Co}(\mathrm{II})$ Complexes with Ligands Derived from Carbonohydrazide. Open Journal of Inorganic Chemistry, 9, 35-52.

https://doi.org/10.4236/ojic.2019.94004

Received: August 9, 2019

Accepted: September 20, 2019

Published: September 23, 2019

Copyright $\odot 2019$ by author(s) and Scientific Research Publishing Inc. This work is licensed under the Creative Commons Attribution International License (CC BY 4.0).

http://creativecommons.org/licenses/by/4.0/

\begin{abstract}
The ligand 1-(1-(pyridin-2-yl)ethylidene)carbonohydrazide $\left(\mathrm{H}_{4} \mathrm{~L}^{1}\right)$ and 1(pyridin-2-ylmethylene)carbonohydrazide $\left(\mathrm{H}_{4} \mathrm{~L}^{2}\right)$ were prepared by reaction of carbonohydrazide with 2-acetylpyridine or pyridine carbaldehyde respectively in a reflux methanol solution. The complexes are prepared by reaction of the ligand with the appropriate metal salt. These complexes are well characterized by elemental analysis, IR and UV spectroscopies and their structure were determined by single X-ray diffraction technic. In the crystal of the dinuclear complex $\left.\left[\mathrm{Mn}_{2}\left(\mathrm{H}_{4} \mathrm{~L}^{1}\right)_{2}\left(\mathrm{H}_{2} \mathrm{O}\right)_{4}\right] \cdot \mathrm{Cl}_{4}, 1\right)$ each $\mathrm{Mn}(\mathrm{II})$ center is seven coordinated by two nitrogen atom and one carbonyl atom of the one ligand and one nitrogen atom and one carbonyl oxygen atom of another ligand molecule. The coordination sphere is completed by two water molecules. Each of the carbonyl oxygen atom acts as bridge between the two $\mathrm{Mn}$ (II) centers. In the mononuclear complex $\left.\left[\mathrm{Co}\left(\mathrm{H}_{4} \mathrm{~L}^{2}\right)\left(\mathrm{NO}_{3}\right)\left(\mathrm{H}_{2} \mathrm{O}\right)_{2}\right] \cdot\left(\mathrm{NO}_{3}\right) ; 2\right)$ the $\mathrm{Co}(\mathrm{II})$ center is heptacoordinated. The ligand acts in tridentate fashion through two nitrogen atoms and one carbonyl oxygen atom. Two water molecules lie in the apical positions. One nitrate group acts in bidentate manner while the other nitrate group remains uncoordinated. In both complexes the coordination polyhedral are best described as a pentagonal bipyramid. The molecules are linked together in each case by multiple hydrogen bond interaction resulting in a three-dimensional network. The crystallographic data has been deposited in Cambridge Crystallographic Data Centre [CCDC No. 1944387 (complex 1) and 1944386 (complex 2)].
\end{abstract}




\section{Keywords}

Carbonohydrazide, Manganese, Cobalt, Complex, X-Ray Diffraction

\section{Introduction}

Transition metal coordination compounds with Schiff bases continue to attract the attention of researchers because of the easier synthesis, the stability of the molecular structures and the large diverse properties observed [1]-[11]. Indeed catalytic [12] [13] [14], optical [15], magnetic [16] [17], fluorescent [18] [19] and biological activities [8] [20] [21] [22] are reported. The complexes derived from the first row of transition metals can give several models of metalloenzymes [23] [24] and metalloproteins [25] [26]. Heptacoordinated manganese (II) and cobalt (II) structures have also attracted a great deal of interest from chemists in recent years [8] [27] [28] [29]. These kind of structures are present in enzymes: catalase [30] [31], ribonucleotide manganese reductase [32] and arginase [33]. In addition to their interests in biology, these complexes are likely to give very interesting magnetic properties. In the literature, dinuclear compounds of manganese or cobalt which exhibit ferromagnetic or antiferromagnetic interactions are largely reported [34] [35] [36]. In recent years, we have prepared different symmetrical Schiff base types from the condensation of carbono or thiocarbono hydrazide and aldehydes or ketones which are subsequently used to prepare dinuclear or tetranuclear metal complexes [37] [38] [39]. In the absence of any particular precautions, the reaction which is a nucleophilic addition of the primary amine on the carbonyl group, proceeds on both arms of the carbonohydrazide. By controlling the conditions of the reaction we prepared a ligand from the monocondensation of carbonohydrazide and acetyl pyridine or pyridine carbaldehyde. The topologies of these dissymmetric ligands lead it to act in tridentate or tetradentate fashions leading fascinating structures. In this context, we report the isolation and complete characterization of this ligand and its $\mathrm{Mn}$ (II) and $\mathrm{Co}$ (II) complexes in which the metal centers are heptacoordinated as showed by crystal $\mathrm{X}$-ray diffraction analysis. The structure of the formed crystals has been by single $\mathrm{X}$-ray diffraction analysis and the data have been deposited in CCDC Cambridge crystallographic data centre.

\section{Experimental}

\subsection{Material and Physical Measurement}

Carbonohydrazide (98\%), 2-acetylpyridine (99\%), 2-pyridinecarboxaldehyde (99\%), $\mathrm{MnCl}_{2} \cdot 4 \mathrm{H}_{2} \mathrm{O}$ (99\%), $\mathrm{Co}\left(\mathrm{NO}_{3}\right)_{2} \cdot 6 \mathrm{H}_{2} \mathrm{O}(99.99 \%)$ and analytical grade methanol were supplied from Aldrich. All chemicals and solvents were used directly without further purification. Elemental analyses of $\mathrm{C}, \mathrm{H}$ and $\mathrm{N}$ were recorded on a VxRio EL Instrument. The FAB mass spectra were recorded using a Micromass Autospec spectrometer using 3-nitrobenzylalcohol as the matrix. Infrared 
spectra were obtained on an FTIR Spectrum Two of Perkin Elmer spectrometer in the $4000-400 \mathrm{~cm}^{-1}$ region. The UV-Visible spectra was recorded on a Perkin Elmer Lambda UV-Vis spectrophotometer. The molar conductance of $1 \times 10^{-3} \mathrm{M}$ in DMSO solutions of the metal complexes was measured at $25^{\circ} \mathrm{C}$ using a WTW LF-330 conductivity meter with a WTW conductivity cell. Room temperature magnetic susceptibilities of the powdered samples were measured using a Johnson Mattey scientific magnetic susceptibility balance (Calibrant: $\mathrm{Hg}\left[\mathrm{Co}(\mathrm{SCN})_{4}\right]$ ). The voltammetric measurements were recorded using a Palm Sens3 type potentiostat controlled by PSTrace software. A glassy carbon working electrode with a radius of $2 \pm 0.1 \mathrm{~mm}$, a stainless steel wire as a counter-electrode and $\mathrm{Ag} / \mathrm{AgCl}$ electrode as a reference were used. Cyclic voltammetry experiments were performed in acetonitrile solution $0.1 \mathrm{M}$ of tetrabutylammonium hexafluorophosphate (TBAHFP) as a supporting electrolyte.

\subsection{Synthesis of the Ligand \\ 1-(1-(Pyridin-2-yl)Ethylidene)Carbonohydrazide: $\mathrm{H}_{4} \mathrm{~L}^{1}$}

To a solution of carbonohydrazide $(3.0 \mathrm{~g}, 0.333 \mathrm{mmol})$ in a mixture of $10 \mathrm{~mL}$ of distillate water and $30 \mathrm{~mL}$ of methanol was added dropwise a solution of 2-acetylpyridine $(4.038 \mathrm{~g}, 0.330 \mathrm{mmol})$ in $10 \mathrm{~mL}$ of methanol. The mixture was stirred under reflux for 4 hours. A white precipitate appears gradually. On cooling, the precipitate was isolated by filtration and successively washed with $2 \times 10$ $\mathrm{mL}$ of hot methanol and dried under $\mathrm{P}_{4} \mathrm{O}_{10}$. The filtrated was stored at $4{ }^{\circ} \mathrm{COn}$ standing for one week crystals suitable for $\mathrm{X}$-ray analysis were isolated. MP: $222^{\circ} \mathrm{C}$. Yield: $86.4 \%$. Analytical for $\mathrm{C}_{8} \mathrm{H}_{11} \mathrm{~N}_{5} \mathrm{O}$ : Calc (found) $\% \mathrm{C}=49.73$ (49.43); \% $\mathrm{H}=5.74$ (5.78); \% $\mathrm{N}=36.25$ (36.21). IR $\left(v, \mathrm{~cm}^{-1}\right): 3306 ; 3086 ; 1671$; 1629; 1578; 1506; 1466, 1141. ${ }^{1} \mathrm{H}$ NMR (dmso-d $\left.\mathrm{d}_{6}, \delta(\mathrm{ppm})\right): 2.36\left(\mathrm{~s}, 3 \mathrm{H},-\mathrm{CH}_{3}\right)$; $4.12\left(\mathrm{~s}, 2 \mathrm{H},-\mathrm{NH}_{2}\right) ; 7.32-8.51\left(\mathrm{~m}, 4 \mathrm{H}, \mathrm{H}_{\mathrm{Py}}\right) ; 8.19$ (s, 1H, $\left.-(\mathrm{C}=\mathrm{O})-\mathrm{NH}-\mathrm{NH}_{2}\right) ; 9.64$ (s, $1 \mathrm{H},-(\mathrm{C}=\mathrm{O})-\mathrm{NH}-(\mathrm{C}=\mathrm{N})-) .{ }^{13} \mathrm{C}$ NMR $\left(\mathrm{dmso}_{6}, \delta(\mathrm{ppm})\right): 157.32\left(\mathrm{CH}_{3}-\mathrm{C}=\mathrm{N}-\right)$; $155.30(\mathrm{C}=\mathrm{O}) ; 148.37$ (Cipso); $145.45\left(\mathrm{C}_{\mathrm{Py}}\right) ; 136.43\left(\mathrm{C}_{\mathrm{Py}}\right) ; 123.47\left(\mathrm{C}_{\mathrm{Py}}\right) ; 120.13$ $\left(\mathrm{C}_{\mathrm{Py}}\right) ; 11.03\left(-\mathrm{CH}_{3}\right)$.

\subsection{Synthesis of the Ligand 1-(Pyridin-2-Ylmethylene)Carbonohydrazide: $\mathrm{H}_{4} \mathrm{~L}^{2}$}

To a solution of carbonohydrazide $(3.0 \mathrm{~g}, 0.333 \mathrm{mmol})$ in a mixture of $10 \mathrm{~mL}$ of distillate water and $30 \mathrm{~mL}$ of methanol was added dropwise a solution of 2-pyridinecarboxaldehyde $(3.5672 \mathrm{~g}, 0.330 \mathrm{mmol})$ in $10 \mathrm{~mL}$ of methanol. The mixture was stirred at reflux for 4 hours. After cooling to room temperature, the orange solution was stored in the refrigerator and a precipitate appears overnight. The compound was isolated by filtration and washed successively with $2 \mathrm{x}$ $10 \mathrm{~mL}$ of cold methanol and $2 \times 10 \mathrm{~mL}$ of diethyl ether before being dried over $\mathrm{P}_{4} \mathrm{O}_{10}$. MP: $165^{\circ} \mathrm{C}-167^{\circ} \mathrm{C}$. Yield: $62.1 \%$. Analytical for $\mathrm{C}_{7} \mathrm{H}_{9} \mathrm{~N}_{5} \mathrm{O}$ : Calc (found) \%C $=46.92$ (46.90); \% $=5.06(5.04) ; \% \mathrm{~N}=39.09$ (39.05). IR $\left(v, \mathrm{~cm}^{-1}\right): 3304 ; 3197$; $1675 ; 1634 ; 1609 ; 1585 ; 1519 ; 1494,1151 .{ }^{1} \mathrm{H}$ NMR $\left(\mathrm{dmso}_{6}, \delta(\mathrm{ppm})\right): 4.08$ (s, $\left.2 \mathrm{H},-\mathrm{NH}_{2}\right) ; 7.30-8.52\left(\mathrm{~m}, 4 \mathrm{H}, \mathrm{H}_{\mathrm{Py}}\right) ; 8.21$ (s, 1H, H-C=N-NH-C=O);10.67 (s, 
$\left.1 \mathrm{H},-(\mathrm{C}=\mathrm{O})-\mathrm{NH}-\mathrm{NH}_{2}-\right),{ }^{13} \mathrm{C}$ NMR $\left(\mathrm{dmso}_{6}, \delta(\mathrm{ppm})\right): 156.27\left(\mathrm{CH}_{3}-\mathrm{C}=\mathrm{N}-\right)$; $155.500(\mathrm{C}=\mathrm{O}) ; 148.79$ (Cipso); $140.46\left(\mathrm{C}_{\mathrm{Py}}\right) ; 136.47\left(\mathrm{C}_{\mathrm{Py}}\right) ; 123.54\left(\mathrm{C}_{\mathrm{Py}}\right) ; 119.50$ $\left(\mathrm{C}_{\mathrm{Py}}\right)($ Scheme 1).

\subsection{Synthesis of the Complexes}

\subsection{1. $\left[\mathrm{Mn}_{2}\left(\mathrm{H}_{4} \mathrm{~L}^{1}\right)_{2}\left(\mathrm{H}_{2} \mathrm{O}\right)_{4}\right] \cdot \mathrm{Cl}_{4}(1)$}

To a suspension of $\mathrm{L}^{1} \mathrm{H}_{4}(0.193 \mathrm{~g}, 1 \mathrm{mmol})$ in $10 \mathrm{ml}$ of methanol was added $\mathrm{MnCl}_{2} \cdot 4 \mathrm{H}_{2} \mathrm{O}(0.1979 \mathrm{~g}, 1 \mathrm{mmol})$. The resulting yellowish mixture was stirred for $30 \mathrm{~min}$. The resulting yellow suspension was stirred at room temperature during one hour. The suspension was filtered and the filtrate was left at room temperature. On standing for one week crystals suitable for X-ray analysis were isolated.<smiles>[R]C(=O)c1ccccn1</smiles><smiles>[R]/C(=N\NC(=O)NN)c1ccccn1</smiles>

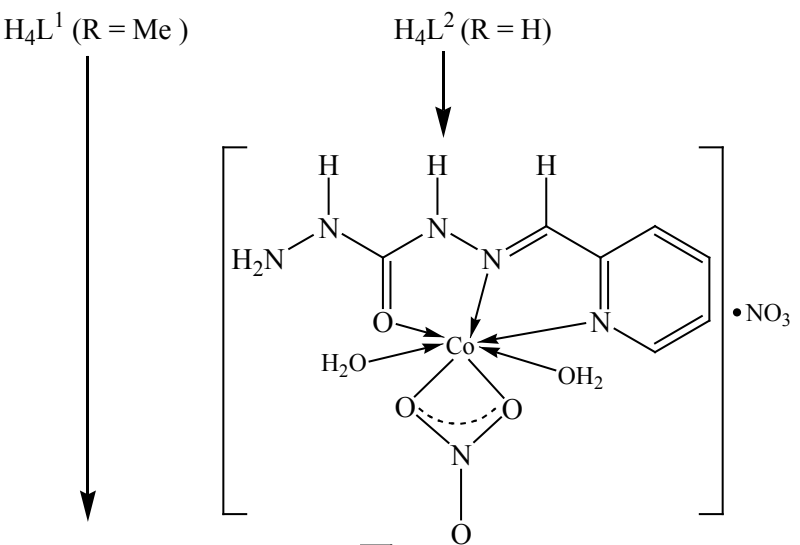

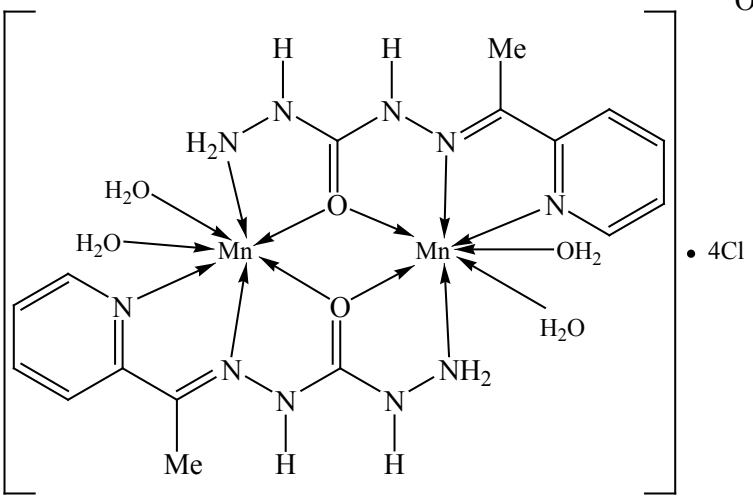

Scheme 1. Preparation of the ligands and the complexes. 
Yield: 74.6 (\%). SM (ESI-TOF) $(\mathrm{m} / z): 194.1\left[\left(\mathrm{H}_{5} \mathrm{~L}\right)\right]^{+} ; 361\left[\mathrm{Mn}\left(\mathrm{H}_{4} \mathrm{~L}\right) \mathrm{Cl}\left(\mathrm{H}_{2} \mathrm{O}\right)_{3} \mathrm{Na}\right]^{2+}$; $440\left[\mathrm{Mn}\left(\mathrm{H}_{4} \mathrm{~L}\right)\left(\mathrm{H}_{3} \mathrm{~L}\right)\right]^{3+} ; 602.97\left[\mathrm{Mn}_{2}\left(\mathrm{H}_{4} \mathrm{~L}\right)_{2}(\mathrm{Cl})\left(\mathrm{H}_{2} \mathrm{O}\right)_{4}\right]^{3+} . \mathrm{IR}\left(\mathrm{cm}^{-1}\right): 3276 \mathrm{~cm}^{-1}$; $3186 \mathrm{~cm}^{-1} ; 3142 \mathrm{~cm}^{-1} ; 3070 \mathrm{~cm}^{-1} ; 1658 \mathrm{~cm}^{-1} ; 1595 \mathrm{~cm}^{-1} ; 1557 \mathrm{~cm}^{-1} ; 1470 \mathrm{~cm}^{-1}$; $1362 \mathrm{~cm}^{-1} ; 1185 \mathrm{~cm}^{-1} ; 1154 \mathrm{~cm}^{-1} ; 1027 \mathrm{~cm}^{-1} ; 829 \mathrm{~cm}^{-1}$. UV-vis (Solution, DMF, $\mathrm{nm}): 219 ; 357 ; 421 . \mu_{\mathrm{eff}}=7.72 \mu_{\mathrm{B}} . \Lambda\left(\Omega^{-1} \cdot \mathrm{cm}^{2} \cdot \mathrm{mol}^{-1}, \mathrm{DMF}\right): 292$.

\subsection{2. [Co( $\left.\left.\mathrm{H}_{4} \mathrm{~L}^{2}\right)\left(\mathrm{NO}_{3}\right)\left(\mathrm{H}_{2} \mathrm{O}\right)_{2}\right] \cdot\left(\mathrm{NO}_{3}\right)$ (2)}

To a suspension of $\mathrm{L}^{2} \mathrm{H}_{4}(0.1792 \mathrm{~g}, 1 \mathrm{mmol})$ in $10 \mathrm{ml}$ of methanol was added $\mathrm{Co}\left(\mathrm{NO}_{3}\right)_{2} \cdot 6 \mathrm{H}_{2} \mathrm{O}(0.2910 \mathrm{~g}, 1 \mathrm{mmol})$ dissolved in $5 \mathrm{~mL}$ of methanol. The resulting brown mixture was stirred for $60 \mathrm{~min}$ at room temperature. The resulting solution was filtered and the filtrate was left at room temperature. On standing for one week crystals suitable for X-ray analysis were isolated. Yield: 36.8 (\%). IR $\left(\mathrm{cm}^{-1}\right): 3227 \mathrm{~cm}^{-1} ; 1637 \mathrm{~cm}^{-1} ; 1578 \mathrm{~cm}^{-1} ; 1540 \mathrm{~cm}^{-1} ; 1455 \mathrm{~cm}^{-1} ; 1402 \mathrm{~cm}^{-1} ; 1380$, $1294 \mathrm{~cm}^{-1} ; 1205 \mathrm{~cm}^{-1} ; 1116 \mathrm{~cm}^{-1} ; 1026 \mathrm{~cm}^{-1} ; 936 \mathrm{~cm}^{-1}$. UV-vis (Solution, DMF, $\mathrm{nm}): 225 ; 321 ; 421 ; 530 . \mu_{\mathrm{eff}}=4.99 \mu_{\mathrm{B}} . \Lambda\left(\Omega^{-1} \cdot \mathrm{cm}^{2} \cdot \mathrm{mol}^{-1}, \mathrm{DMF}\right): 83.1$.

\subsection{Crystal Structure Determination and Refinement}

Crystals suitable for X-diffraction, of the reported compounds, were grown by slow evaporation of $\mathrm{MeOH}$ solution of the complex. Details of the X-rays crystal structure solution and refinement are given in Table 1 . Diffraction data were collected using an ENRAF NONIUS Kappa CCD diffractometer with graphite monochromatized MoK $\alpha$ radiation $(\lambda=0.71073 \AA$ ). All data were corrected for Lorentz and polarization effects. No absorption correction was applied. Complex scattering factors were taken from the program package SHELXTL [40]. The structures were solved by direct methods which revealed the position of all non-hydrogen atoms. All the structures were refined on $F^{2}$ by a full-matrix least-squares procedure using anisotropic displacement parameters for all nonhydrogen atoms [34]. The hydrogen atoms of water molecules and $\mathrm{NH}$ groups were located in the Fourier difference maps and refined. Others $\mathrm{H}$ atoms $(\mathrm{CH}$ and $\mathrm{CH}_{3}$ groups) were geometrically optimized and refined as riding model by AFIX instructions. Molecular graphics were generated using ORTEP-3 [41].

\section{Results and Discussion}

\subsection{General Study}

The infrared spectrum of each molecule ligand shows the presence of two bands in the range $3310 \mathrm{~cm}^{-1}$ and $3080 \mathrm{~cm}^{-1}$ attributable to the vibrations $v_{\mathrm{N}-\mathrm{H}}$ of the ligand. The vibration bands relative to $v_{\mathrm{C}=\mathrm{O}}$ and $v_{\mathrm{C}=\mathrm{N}}$ are respectively located at $1671 \mathrm{~cm}^{-1}$ and $1634 \mathrm{~cm}^{-1}$ for $\mathrm{H}_{4} \mathrm{~L}^{1}$ and $1675 \mathrm{~cm}^{-1}$ and $1639 \mathrm{~cm}^{-1}$ for $\mathrm{H}_{4} \mathrm{~L}^{2}$. Bands assignable $v_{\mathrm{C}=\mathrm{N}}$ and $v_{\mathrm{C}=\mathrm{C}}$ of the pyridine ring are located between $1460 \mathrm{~cm}^{-1}$ and $1590 \mathrm{~cm}^{-1}$ [42]. The vibration of the $\mathrm{N}-\mathrm{N}$ bond are pointed at $c a .1146 \mathrm{~cm}^{-1}$ for both ligands. The ${ }^{1} \mathrm{H}$ NMR spectra of the ligands recorded in $\mathrm{dmso}-\mathrm{d}_{6}$ and show similar signals. The difference is due to the presence of a methyl group on the imino carbon atom for $\mathrm{L}^{1} \mathrm{H}_{4}$ instead of imino hydrogenatom as for $\mathrm{L}^{2} \mathrm{H}_{4}$. The 
Table 1. Crystal data and data collection details of the complexes (1) and (2).

\begin{tabular}{|c|c|c|}
\hline Chemical formula & $\mathrm{C}_{16} \mathrm{H}_{30} \mathrm{Mn}_{2} \mathrm{~N}_{10} \mathrm{O}_{6} \cdot 4(\mathrm{Cl})$ & $\mathrm{C}_{7} \mathrm{H}_{13} \mathrm{CoN}_{6} \mathrm{O}_{6} \cdot \mathrm{NO}_{3}(2)$ \\
\hline$M_{\mathrm{r}}$ & 710.18 & 398.16 \\
\hline Crystal system & Triclinic & Triclinic \\
\hline Space group & $P-1$ & $P-1$ \\
\hline Temperature (K) & 293 & 293 \\
\hline$a(\AA)$ & $8.7932(2)$ & $8.4248(2)$ \\
\hline$b(\AA)$ & $9.1070(2)$ & $8.7674(2)$ \\
\hline$c(\AA)$ & $9.9348(3)$ & $10.6885(2)$ \\
\hline$\alpha\left({ }^{\circ}\right)$ & $75.460(2)$ & $82.151(2)$ \\
\hline$\beta\left(^{\circ}\right)$ & $67.174(2)$ & $86.273(2)$ \\
\hline$\gamma\left({ }^{\circ}\right)$ & $81.729(2)$ & $81.732(2)$ \\
\hline$V\left(\AA^{3}\right)$ & $708.83(3)$ & $773.14(3)$ \\
\hline$Z$ & 1 & 2 \\
\hline Radiation type & Mo $K a$ & Mo $K a$ \\
\hline$\mu\left(\mathrm{mm}^{-1}\right)$ & 1.32 & 1.17 \\
\hline Crystal size (mm) & $0.40 \times 0.30 \times 0.15$ & $0.34 \times 0.22 \times 0.10$ \\
\hline$T_{\min }, T_{\max }$ & $0.574,1.000$ & $0.763,1.000$ \\
\hline No. of measured reflections & 15348 & 29332 \\
\hline Independent reflections & 3394 & 3611 \\
\hline Observed reflections $[I>2 \sigma(I)]$ & 3030 & 3296 \\
\hline$R_{\text {int }}$ & 0.048 & 0.027 \\
\hline$R\left[F^{2}>2 \sigma\left(F^{2}\right)\right]$ & 0.026 & 0.045 \\
\hline$w R\left(F^{2}\right)$ & 0.069 & 0.130 \\
\hline Data/parameters/restraints & $3389 / 192 / 5$ & $3611 / 269 / 0$ \\
\hline GOF & 1.07 & 1.07 \\
\hline$\Delta \rho_{\max }, \Delta \rho_{\min }\left(\mathrm{e} \cdot \AA^{-3}\right)$ & $0.28,-0.28$ & $1.00,-0.57$ \\
\hline
\end{tabular}

presence of a singlet signal incorporating two protons attributable to $\mathrm{NH}_{2}$ at 4.08 ppm for both spectra in indicative of the mono condensation of the carbono hydrazide with the ketoprecursors. The ${ }^{13} \mathrm{C}$ NMR spectra are similar except the presence of a signal at $11.03 \mathrm{ppm}$ relative to the presence of a methyl group in $\mathrm{H}_{4} \mathrm{~L}^{1}$. The FAB mass spectrometry of the compound $\left[\mathrm{Mn}_{2}\left(\mathrm{H}_{4} \mathrm{~L}^{1}\right)_{2}\left(\mathrm{H}_{2} \mathrm{O}\right)_{4}\right] \cdot \mathrm{Cl}_{4}$ gave clear evidence of fragmentation of the complex. The parent ion expected at $710.16 \mathrm{amu}$ was not observed. The observed mass/charge ratio of $602.97 \mathrm{amu}$, $440 \mathrm{amu}, 361 \mathrm{amu}$ and $194.10 \mathrm{amu}$ compared to the calculated exact mass of $603.08 \mathrm{amu}, 440.12 \mathrm{amu}, 360.63 \mathrm{amu}$ and $194.21 \mathrm{amu}$ are respectively due to the fragments $\left[\mathrm{Mn}_{2}\left(\mathrm{H}_{4} \mathrm{~L}\right)_{2}(\mathrm{Cl})\left(\mathrm{H}_{2} \mathrm{O}\right)_{4}\right]^{3+},\left[\mathrm{Mn}\left(\mathrm{H}_{4} \mathrm{~L}\right)\left(\mathrm{H}_{3} \mathrm{~L}\right)\right]^{3+},\left[\mathrm{Mn}\left(\mathrm{H}_{4} \mathrm{~L}\right) \mathrm{Cl}\left(\mathrm{H}_{2} \mathrm{O}\right)_{3} \mathrm{Na}\right]^{2+}$, and $\left[\left(\mathrm{H}_{5} \mathrm{~L}\right)\right]^{+}$. Upon coordination the $v_{\mathrm{C}=\mathrm{O}}$ and the $v_{\mathrm{C}=\mathrm{N}}$ were strongly shifted to low frequencies in both spectra. For the $\mathrm{Mn}(\mathrm{II})$ complex the $v_{\mathrm{C}=\mathrm{O}}$ and the $v_{\mathrm{C}=\mathrm{N}}$ 
are respectively pointed at $1658 \mathrm{~cm}^{-1}$ and $1595 \mathrm{~cm}^{-1}$ while the spectrum of the $\mathrm{Co}(\mathrm{II})$ complex show the $v_{\mathrm{C}=\mathrm{O}}$ and the $v_{\mathrm{C}=\mathrm{N}}$ band at $1637 \mathrm{~cm}^{-1}$ and $1578 \mathrm{~cm}^{-1}$. These shifts are indicative of the involvement of the carbono oxygen atom and the nitrogen atom of the azomethine in the complexation with $\mathrm{Mn}$ (II) and $\mathrm{Co}$ (II) in both cases [43] [44]. In both spectrum broad absorption bands appear at $3276 \mathrm{~cm}^{-1}$ and $3227 \mathrm{~cm}^{-1}$ for the complexes of $\mathrm{Mn}$ (II) and $\mathrm{Co}$ (II) respectively. These bands are due to the presence of a coordinated water molecule [45]. Additional bands due to the nitrate moieties appears. The sharp and intense band at $1380 \mathrm{~cm}^{-1}$ is attributed to the free nitrate group. The three absorption bands occurring at $1455 \mathrm{~cm}^{-1}, 1294 \mathrm{~cm}^{-1}$ and $1026 \mathrm{~cm}^{-1}$ respectively attributable to $v_{1}$ $\left(v_{\mathrm{N}=\mathrm{O}}\right), v_{5}\left(v_{\mathrm{asNO} 2}\right)$ and $v_{2}\left(v_{\mathrm{sNO} 2}\right)$ clearly identify a nitrate group coordinated in bidentate fashion [37]. In fact the separation $\Delta v=v_{1}-v_{5}$ is used as criterion of differentiation of the different modes of coordination of the nitrate moiety. The $\Delta v$ value of $161 \mathrm{~cm}^{-1}$ is in accordance with the presence of bidentate nitrate group [45]. In the UV-vis spectra of the monohydrazone ligands two bands are observed at 233 and $318 \mathrm{~nm}$ for $\mathrm{H}_{4} \mathrm{~L}^{1}$ and at 235 and $315 \mathrm{~nm}$ for $\mathrm{H}_{4} \mathrm{~L}^{2}$. For both spectra the first band is attributable to the $n \rightarrow \pi^{*}$ transitions in aromatic rings while the second band is assignable to the $n \rightarrow \pi^{*}$ transition. The electronic spectra of the manganese complex in DMF shows three main bands at 219, 357 and $421 \mathrm{~nm}$ and the cobalt (II) complex in DMF exhibits three main bands around 225, 321 and $421 \mathrm{~nm}$ and a shoulder around $530 \mathrm{~nm}$. By comparing these bands to the absorption in the spectra of the free ligand, bathochromic shifts is observed for the maxima bands of the free ligand. The band observed at $357 \mathrm{~nm}$ for $\mathrm{Mn}$ (II) complex and the band pointed at $321 \mathrm{~nm}$ for Co(II) complex are assigned to the aromatic ring transition $\pi \rightarrow \pi^{*}$ and the other bands are attributed to the $n \rightarrow \pi^{*}$ transitions of $\mathrm{C}=\mathrm{N}$ chromophore. The values of the conductance of the two complexes in DMF are $192 \Omega^{-1} \cdot \mathrm{cm}^{2} \cdot \mathrm{mol}^{-1}$ for the manganese (II) complex which is $2: 1$ electrolyte and $83.1 \Omega^{-1} \cdot \mathrm{cm}^{2} \cdot \mathrm{mol}^{-1}$ for the cobalt (II) complex which is $1: 1$ electrolyte in nature [46]. The magnetic susceptibility measurements of the complexes were performed at room temperature. The value of $7.72 \mu_{\mathrm{B}}$ for the manganese complex is less than the expected value of ca.10 $\mu_{\mathrm{B}}$ for two $\mathrm{Mn}$ (II) ions, indicating the presence of two metal atoms per molecule which are in weak antiferromagnetic coupling interaction. For the complex of cobalt (II) the magnetic moment value of $4.99 \mu_{\mathrm{B}}$ is in the range expected for a mononuclear hepta coordinated cobalt (II) complex [28].

\subsection{Description of the Structures}

Suitable single-crystals for X-ray diffraction of the $\mathrm{Mn}$ (II) and $\mathrm{Co}$ (II) complexes were obtained by slow solvent evaporation at room temperature. Crystal data, collection and refinement parameters are listed in Table 1 . Selected bond lengths and angles are summarized in Table 2. Hydrogen bond data for complexes 1 and 2 are gathered in Table 3. Figures 1-4 displays the asymmetric unit and the packing diagrams of the two compounds. 
Table 2. Selected bond lengths ( $(\AA)$ and angles $\left({ }^{\circ}\right)$ for the complexes (1) and (2).

\begin{tabular}{|c|c|c|c|}
\hline Mn1-O3W & $2.1454(11)$ & Co1-O1 & $2.267(2)$ \\
\hline $\mathrm{Mn} 1-\mathrm{O} 2 \mathrm{~W}$ & $2.1606(11)$ & Co1-O3 & $2.104(2)$ \\
\hline Mn1-O1 & $2.2135(10)$ & Co1-O4 & $2.092(2)$ \\
\hline $\mathrm{Mn} 1-\mathrm{O} 1^{\mathrm{i}}$ & $2.3219(9)$ & Co1-O5 & $2.212(2)$ \\
\hline $\mathrm{Mn} 1-\mathrm{N} 4^{\mathrm{i}}$ & $2.3247(11)$ & Co1-O6 & $2.298(3)$ \\
\hline Mn1-N1 & $2.5223(13)$ & Co1-N1 & $2.192(2)$ \\
\hline Mn1-N5i & $2.2968(12)$ & Co1-N0aa & $2.119(2)$ \\
\hline $\mathrm{O} 3 \mathrm{~W}-\mathrm{Mn} 1-\mathrm{O} 2 \mathrm{~W}$ & $169.82(5)$ & O3-Co1-O1 & $89.79(8)$ \\
\hline O3W-Mn1-O1 & $87.86(4)$ & O4-Co1-O1 & $87.90(8)$ \\
\hline $\mathrm{O} 2 \mathrm{~W}-\mathrm{Mn} 1-\mathrm{O} 1$ & $89.17(5)$ & O4-Co1-O3 & $175.31(8)$ \\
\hline O3W-Mn1-N5i & $90.22(4)$ & O5-Co1-O1 & $75.71(8)$ \\
\hline $\mathrm{O} 2 \mathrm{~W}-\mathrm{Mn} 1-\mathrm{N} 5^{\mathrm{i}}$ & $89.22(5)$ & O5-Co1-O3 & $88.23(9)$ \\
\hline $\mathrm{O} 1-\mathrm{Mn} 1-\mathrm{N} 5^{\mathrm{i}}$ & $159.89(4)$ & O5-Co1-O4 & $87.24(9)$ \\
\hline $\mathrm{O} 3 \mathrm{~W}-\mathrm{Mn} 1-\mathrm{O} 1^{\mathrm{i}}$ & $98.61(5)$ & O6-Co1-O1 & $131.55(8)$ \\
\hline $\mathrm{O} 2 \mathrm{~W}-\mathrm{Mn} 1-\mathrm{O} 1^{\mathrm{i}}$ & $89.04(4)$ & O6-Co1-O3 & $91.92(10)$ \\
\hline $\mathrm{O} 1-\mathrm{Mn} 1-\mathrm{O} 1^{\mathrm{i}}$ & $65.78(4)$ & O6-Co1-O4 & $86.56(9)$ \\
\hline $\mathrm{N} 5^{\mathrm{i}}-\mathrm{Mn} 1-\mathrm{O} 1^{\mathrm{i}}$ & $134.22(4)$ & O6-Co1-O5 & $55.96(8)$ \\
\hline $\mathrm{O} 3 \mathrm{~W}-\mathrm{Mn} 1-\mathrm{N} 4^{\mathrm{i}}$ & $89.02(5)$ & N1-Co1-O1 & $145.80(8)$ \\
\hline $\mathrm{O} 2 \mathrm{~W}-\mathrm{Mn} 1-\mathrm{N} 4^{\mathrm{i}}$ & $100.24(5)$ & $\mathrm{O} 1-\mathrm{C} 7$ & $1.214(3)$ \\
\hline $\mathrm{O} 1-\mathrm{Mn} 1-\mathrm{N} 4^{\mathrm{i}}$ & $131.13(4)$ & N1-Co1-O3 & $89.45(8)$ \\
\hline $\mathrm{N} 5^{\mathrm{i}}-\mathrm{Mn} 1-\mathrm{N} 4^{\mathrm{i}}$ & $68.80(4)$ & N1-Co1-O4 & $94.75(8)$ \\
\hline $\mathrm{O} 1^{\mathrm{i}}-\mathrm{Mn} 1-\mathrm{N} 4^{\mathrm{i}}$ & $66.56(4)$ & N1-Co1-O5 & $138.42(8)$ \\
\hline O3W-Mn1-N1 & $87.18(5)$ & N1-Co1-O6 & $82.65(8)$ \\
\hline $\mathrm{O} 2 \mathrm{~W}-\mathrm{Mn} 1-\mathrm{N} 1$ & $82.68(5)$ & N0aa-Co1-O1 & $71.50(8)$ \\
\hline O1-Mn1-N1 & $67.72(4)$ & N0aa-Co1-O3 & $89.51(9)$ \\
\hline $\mathrm{N} 5^{\mathrm{i}}-\mathrm{Mn} 1-\mathrm{N} 1$ & $92.20(4)$ & N0aa-Co1-O4 & $93.63(8)$ \\
\hline $\mathrm{O} 1^{\mathrm{i}}-\mathrm{Mn} 1-\mathrm{N} 1$ & $132.81(4)$ & N0aa-Co1-O5 & $147.14(8)$ \\
\hline $\mathrm{N} 4^{\mathrm{i}}-\mathrm{Mn} 1-\mathrm{N} 1$ & $160.62(4)$ & N0aa-Co1-O6 & $156.90(9)$ \\
\hline N2-N1-Mn1 & $107.78(8)$ & N0aa-Co1-N1 & $74.30(8)$ \\
\hline
\end{tabular}

Symmetry code: (i) $-\mathrm{x}+1,-\mathrm{y}+1,-\mathrm{z}+1$.

Table 3. Hydrogen bonds for the complexes (1) and (2).

\begin{tabular}{ccccc}
\hline \multicolumn{5}{c}{ Complex 1} \\
\hline$D-\mathrm{H} \cdots A$ & $D-\mathrm{H}$ & $\mathrm{H} \cdots A$ & $D \cdots A$ & $D-\mathrm{H} \cdots A$ \\
\hline $\mathrm{N} 1-\mathrm{H} 1 \mathrm{~A} \cdots \mathrm{Cl}^{\mathrm{i}}$ & 0.89 & 2.68 & $3.4728(14)$ & 149.7 \\
$\mathrm{~N} 2-\mathrm{H} 2 \mathrm{~N} \cdots \mathrm{Cl} 2^{\mathrm{ii}}$ & $0.81(2)$ & $2.689(19)$ & $3.2518(14)$ & $128.3(16)$ \\
$\mathrm{N} 2-\mathrm{H} 2 \mathrm{~N} \cdots \mathrm{Cl} 2^{\mathrm{iii}}$ & $0.81(2)$ & $2.71(2)$ & $3.3574(14)$ & $138.2(16)$ \\
$\mathrm{N} 3-\mathrm{H} 3 \mathrm{~N} \cdots \mathrm{Cl}{ }^{\mathrm{iii}}$ & $0.812(19)$ & $2.324(19)$ & $3.1125(13)$ & $163.9(17)$ \\
$\mathrm{C} 3-\mathrm{H} 32 \cdots \mathrm{Cl} 2^{\mathrm{iii}}$ & 0.96 & 2.91 & $3.7900(17)$ & 153.4 \\
$\mathrm{C} 3-\mathrm{H} 34 \cdots \mathrm{N} 3^{\mathrm{iii}}$ & 0.96 & 2.67 & $3.633(2)$ & 175.9 \\
$\mathrm{C} 8-\mathrm{H} 8 \cdots \mathrm{Cl}{ }^{\mathrm{ii}}$ & 0.93 & 2.91 & $3.5245(17)$ & 124.5 \\
$\mathrm{O} 2 \mathrm{~W}-\mathrm{H} 2 \mathrm{~W} 1 \cdots \mathrm{Cl} 1^{\mathrm{i}}$ & $0.811(15)$ & $2.286(15)$ & $3.0939(12)$ & $175(2)$ \\
$\mathrm{O} 2 \mathrm{~W}-\mathrm{H} 2 \mathrm{~W} 2 \cdots \mathrm{Cl} 1$ & $0.798(15)$ & $2.323(16)$ & $3.1133(12)$ & $171(2)$ \\
\hline
\end{tabular}




\section{Continued}

\begin{tabular}{|c|c|c|c|c|}
\hline $\mathrm{O} 3 \mathrm{~W}-\mathrm{H} 3 \mathrm{~W} 1 \cdots \mathrm{Cl} 2^{\mathrm{v}}$ & $0.824(15)$ & $2.204(16)$ & $3.0255(12)$ & $175(2)$ \\
\hline $\mathrm{O} 3 \mathrm{~W}-\mathrm{H} 3 \mathrm{~W} 2 \cdots \mathrm{Cl}^{\mathrm{v}}$ & $0.800(16)$ & $2.352(17)$ & $3.1424(13)$ & $169(2)$ \\
\hline \multicolumn{5}{|c|}{ Complex 2} \\
\hline$D-\mathrm{H} \cdots A$ & $D-\mathrm{H}$ & $\mathrm{H} \cdots A$ & $D \cdots A$ & $D-\mathrm{H} \cdots A$ \\
\hline $\mathrm{O} 4-\mathrm{H} 4 \mathrm{a} \cdots \mathrm{O}^{\mathrm{vi}}$ & $0.851(9)$ & 2.053 & 2.902 & 174.24 \\
\hline $\mathrm{O} 4-\mathrm{H} 4 \mathrm{a} \cdots \mathrm{O}^{\mathrm{vi}}$ & $0.851(9)$ & 2.687 & 3.220 & 122.02 \\
\hline $\mathrm{O} 44^{\mathrm{vi}}-\mathrm{H} 4 \mathrm{a} \cdots \mathrm{O} 7$ & $0.851(9)$ & 2.053 & 2.902 & 174.24 \\
\hline $\mathrm{O} 4^{\mathrm{vi}}-\mathrm{H} 4 \mathrm{a} \cdots \mathrm{O} 6$ & $0.851(9)$ & 2.687 & 3.220 & 122.02 \\
\hline $\mathrm{O} 4-\mathrm{H} 4 \mathrm{~b} \cdots \mathrm{O} 8$ & $0.851(9)$ & 2.381 & 3.194 & 160.27 \\
\hline $\mathrm{O} 4-\mathrm{H} 4 \mathrm{~b} \cdots \mathrm{O} 9$ & $0.851(9)$ & 2.173 & 2.911 & 145.53 \\
\hline $\mathrm{N} 3^{\mathrm{vii}}-\mathrm{H} 3 \cdots \mathrm{O} 10$ & $0.860(3)$ & 2.088 & 2.846 & 146.61 \\
\hline $\mathrm{C}^{\mathrm{vii}}-\mathrm{H} 6 \cdots \mathrm{O} 10$ & $0.929(3)$ & 2.286 & 3.045 & 138.49 \\
\hline
\end{tabular}

Symmetry codes: (i) $-\mathrm{x},-\mathrm{y}+1,-\mathrm{z}+1$; (ii) $\mathrm{x}, \mathrm{y}+1$, $\mathrm{z}$; (iii) $-\mathrm{x}+1,-\mathrm{y}+1,-\mathrm{z}$; (iv) $-\mathrm{x}+1,-\mathrm{y},-\mathrm{z}+1$; (v) $-\mathrm{x}$ $+1,-y+1,-z+1$; (vi) $-\mathrm{x}, 1-\mathrm{y}, 1-\mathrm{z}$; (vii) $1-\mathrm{x},-\mathrm{y}, 2-\mathrm{z}$.

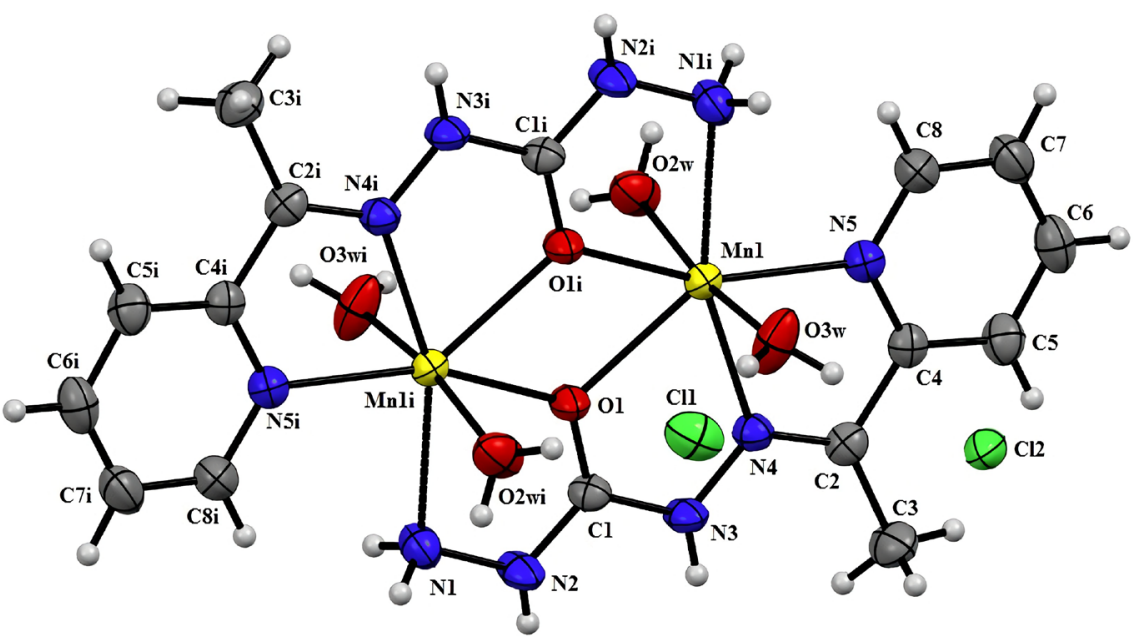

Figure 1. ORTEP plot (30\% probability ellipsoids) showing the molecule structure of the complex 1 .

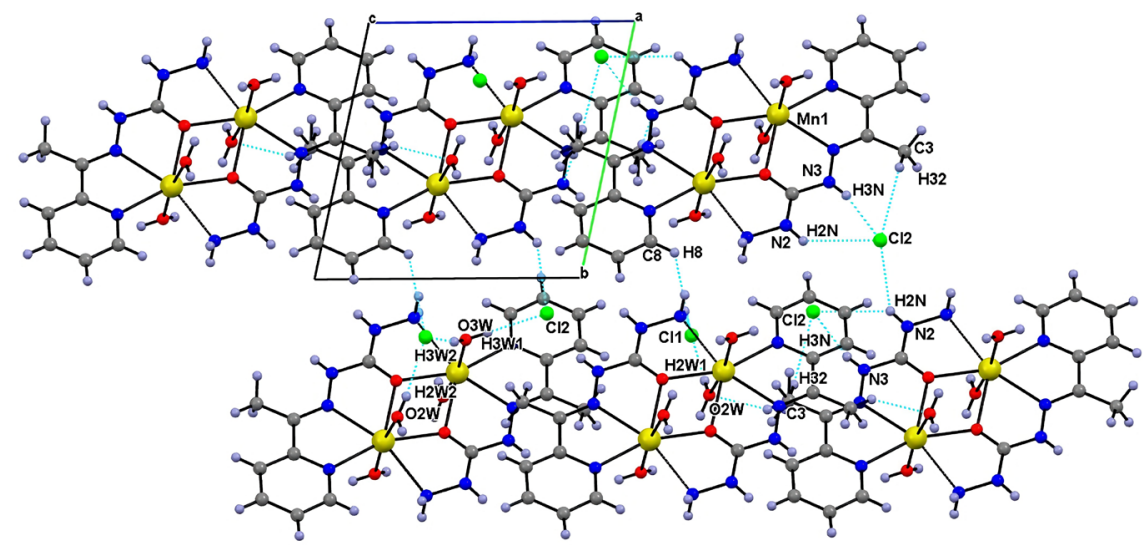

Figure 2. Hydrogen bonds in complex 1. 


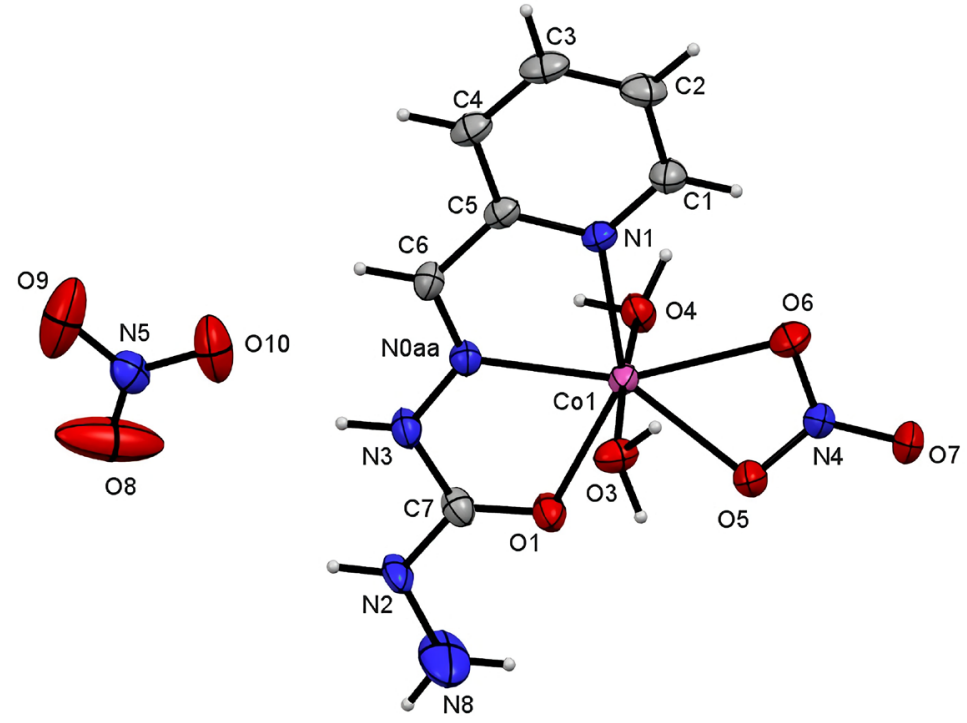

Figure 3. ORTEP plot (30\% probability ellipsoids) showing the molecule structure of the complex 2 .

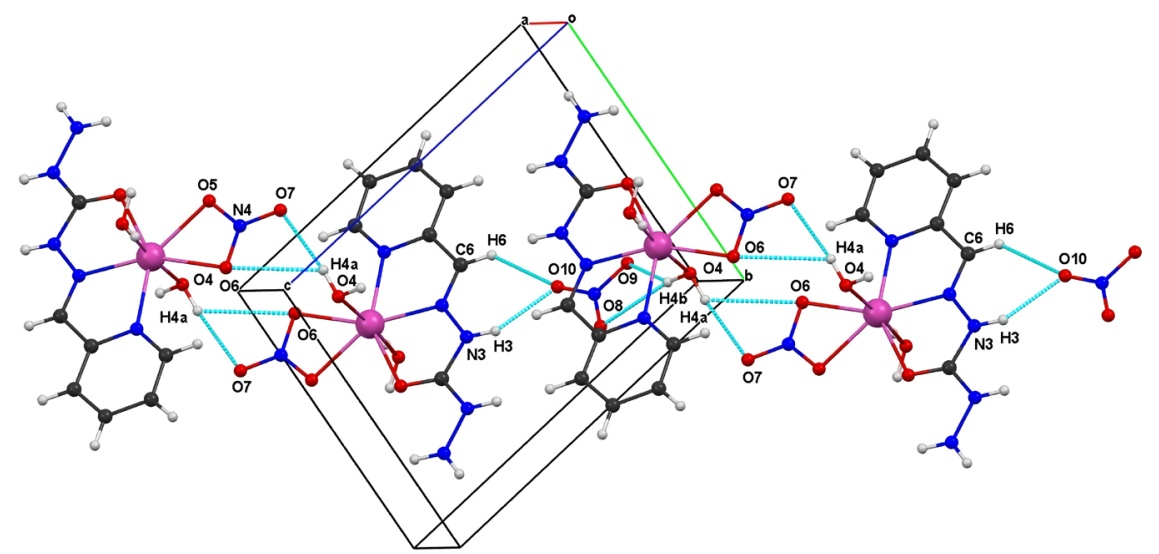

Figure 4. Hydrogen bonds in complex 2.

\subsubsection{Complex 1}

The $\left[\mathrm{Mn}_{2}\left(\mathrm{H}_{4} \mathrm{~L}^{1}\right)_{2}\left(\mathrm{H}_{2} \mathrm{O}\right)_{4}\right] \cdot 4 \mathrm{Cl}$ complex crystallizes in the triclinic system with the space group P-1. The view of the structure of the complex 1 is depicted in Figure 1. The asymmetric unit contains two manganese (II) atoms, two organic ligand molecules, four coordinated water molecules and four free chloride anions. Each of the ligand molecules acts in tetradentate fashion through one nitrogen atom from the pyridine, one imino nitrogen atom, one nitrogen atom amino and one carbonyl oxygen atom which acts as bridge between the two manganese (II) atoms. Each of the two metal ions $\mathrm{Mn}(\mathrm{II})$ is heptacoordinated and the coordination polyhedron of the $\mathrm{Mn}(\mathrm{II})$ center is best described as a distorted pentagonal bipyramid with a $\mathrm{MnN}_{3} \mathrm{O}_{4}$ chromophore. Each equatorial planes around each $\mathrm{Mn}$ (II) atom is occupied by a pyridine nitrogen atom, an imino nitrogen atom, one oxygen atom from the same ligand, one carbonyl bridged oxygen atom and one amino nitrogen atom from another ligand molecule. The apical positions are 
occupied by two oxygen atoms of the coordinated water molecules. The angles formed between the metal center and the ligand donor atoms in equatorial position are different from the ideal angle for a regular pentagon $\left(72^{\circ}\right)\left[\mathrm{N} 5^{\mathrm{i}}-\mathrm{Mn} 1-\mathrm{N} 4^{\mathrm{i}}\right.$ $=68.80(4)^{\circ}, \mathrm{O} 1^{\mathrm{i}}-\mathrm{Mn} 1-\mathrm{N} 4^{\mathrm{i}}=66.56(4)^{\circ}, \mathrm{N} 5^{\mathrm{i}}-\mathrm{Mn} 1-\mathrm{N} 1=92.20(4)^{\circ}, \mathrm{O} 1-\mathrm{Mn} 1-\mathrm{N} 1$ $=67.72(4)^{\circ}, \mathrm{O} 1-\mathrm{Mn} 1-\mathrm{O} 1^{\mathrm{i}}=65.78(4)^{\circ}$ ] with a sum of $361.1^{\circ}$ [47]. The apical angle formed by the water oxygen atoms in axial positions around the manganese (II) atom $\left[\mathrm{O} 2 \mathrm{w}-\mathrm{Mn} 1-\mathrm{O} 3 \mathrm{w}=169.82(5)^{\circ}\right]$ significantly deviate from the ideal value of $180^{\circ}$ (Table 2). The angles $\mathrm{Mn} 1-\mathrm{O} 1-\mathrm{Mn} 1^{\mathrm{i}}$ and $\mathrm{O} 1-\mathrm{Mn}-\mathrm{O} 1^{\mathrm{i}}$ are respectively $114.22(4)^{\circ}$ and $65.78(4)^{\circ}$. For the Mn atom the apical position is occupied by the water oxygen atoms Ow2 and OW3 with 2.1606 (11) $\AA$ and 2.1454 (11) $\AA$ distance. These distances are shorter than those of the equatorial bonds [Mn1-O1 = 2.2135 (10) $\AA, \mathrm{Mn} 1-\mathrm{N} 5 \mathrm{i}=2.2968$ (12) $\mathrm{A}, \mathrm{Mn} 1-\mathrm{O} 1 \mathrm{i}=2.3219$ (9) $\AA$, Mn1-N4i = 2.3247 (11) $\AA$ and Mn1-N1 = 2.5223 (13) $\AA$ ] (Table 2) and are comparable to those found in similar complex [27]. The interatomic distance O1-C1 of 1.2433 (16) $\AA$ is close proximity to that observed in the structure of the free ligand which is of the order of 1.231 (3) $\AA$. This fact is indicative of double character bond upon complexation with the $\mathrm{Mn}$ (II) ion. Each mononuclear $\mathrm{Mn}$ (II) molecule complex is connected to another complex molecule by hydrogen bonding interactions leading to the formation of a supramolecular chain structure propagating along the a axis. The chains are connected by hydrogen bonding interaction of type $\mathrm{N}-\mathrm{H} . . . \mathrm{Cl}, \mathrm{C}-\mathrm{H} . . . \mathrm{Cl}, \mathrm{Ow}-\mathrm{H} \ldots \mathrm{Cl}$, and $\mathrm{C}-\mathrm{H} \ldots \mathrm{N}$. The uncoordinated chloride anion acts via hydrogen bonds as bridge between the chains leading to the formation of a 3D supramolecular structure (Figure 2, Table 3).

\subsubsection{Complex 2}

The compound $\left[\mathrm{Co}\left(\mathrm{H}_{4} \mathrm{~L}_{\mathrm{D}}\right)\left(\mathrm{H}_{2} \mathrm{O}\right)_{2}\left(\mathrm{NO}_{3}\right)\right] \cdot \mathrm{NO}_{3}$ crystallizes in the triclinic system with a P-1 space group. The view of the structure of the complex 2 is depicted in Figure 3 . The asymmetric unit is composed by a cobalt (II) atom coordinated to one organic ligand molecule, one bidentated coordinated nitrate anion, two coordinated water molecules and one uncoordinated nitrate ion. The ligand acts in tridentate manner through the oxygen atom of the carbonyl moiety, the imino nitrogen atom and the pyridine nitrogen atom. The cobalt ion is situated in a $\mathrm{N}_{2} \mathrm{O}_{5}$ core and the environment is best described as pentagonal bipyramid geometry (Figure 3 ). The equatorial plane around the $\mathrm{Co}(\mathrm{II})$ ion is occupied by the three donor atoms from the organic ligand molecule and the two oxygen atoms of the coordinated nitrate group while the apical positions are occupied by the two oxygen atoms of the coordinated water molecules. The angles formed between the equatorial atoms and the $\mathrm{Co}(\mathrm{II})$ ion are: N0aa-Co1-O1 $=71.50(8)^{\circ}$, N0aa-Co1-N1 $=74.30(8)^{\circ}$, N1-Co1-O6 $=55.96(8)^{\circ}$, O5-Co1-O1 = $75.71(8)^{\circ}$ and are different from the ideal angle value of $72^{\circ}$ for a pentagonal basal plan [48]. The angle O4-Co1-O3 formed between the apical atoms and the Co(II) ion deviated from the ideal value of $180^{\circ}$ with a value of $175.31(8)^{\circ}$. The sum of the angles around $\mathrm{Co}(\mathrm{II})$ is $360.12^{\circ}$ and is very close to the ideal sum of $360^{\circ}$. These 
deviations are indicative of a distortion of geometry around the cobalt center which is best described as a distorted pentagonal bipyramid. The equatorial distances $[\mathrm{Co} 1-\mathrm{O} 1=2.267$ (2) $\AA$, Co1-O5 = 2.212 (2) $\AA$, Co1-O6 = 2.298 (3) $\AA$, Co1-N1 $=2.192(2) \AA$ and Co1-N0aa $=2.119(2) \AA]$ are longer that of the axial distances $[\mathrm{Co} 1-\mathrm{O} 3=2.104$ (2) $\AA, \mathrm{Co1}-\mathrm{O} 4=2.092$ (2) $\AA]$ (Table 2) and are comparable to the values reported for a seven coordinated cobalt(II) complex [29].

In the crystal, the complex molecules are linked by hydrogen bonds, giving rise to a three-dimensional network (Figure 4, Table 3). The structure is built up from pentagonal bipyramids around the $\mathrm{Co}(\mathrm{II})$ atom, which are assembled in layers parallel to the $b c$ plane. These layers are interconnected by hydrogen bonds. The coordinating axial water molecule points into the interlayer space and acts as a hydrogen-bond donor towards oxygen atom $\mathrm{O}-\mathrm{NO}_{2}$ of the coordinated nitrate (Figure 4) O1W-H1WB... $\mathrm{ONO}_{2}$. Within a layer, the molecules are not interconnected by hydrogen bonds.

\subsubsection{Electrochemistry Study $\left[\mathrm{Mn}_{2}\left(\mathrm{H}_{4} \mathrm{~L}\right)_{2}\left(\mathrm{H}_{2} \mathrm{O}\right)_{2}\right] \cdot 4 \mathrm{Cl}$}

The electrochemical properties of the Mn(II) complex was studied by cyclic voltammeter using a graphite carbon working electrode and a Pt-wire auxiliary electrode in acetonitrile using $\mathrm{LiClO}_{4}$ a the supporting electrolyte. The voltammetric parameters were studied in the scan rate interval $100-200 \mathrm{mVs}^{-1}$. In Figure 5 describes the electrochemical behavior of the complex in acetonitrile medium. The cyclic votammogram of the complex $\left[\mathrm{Mn}_{2}\left(\mathrm{H}_{4} \mathrm{~L}\right)_{2}\left(\mathrm{H}_{2} \mathrm{O}\right)_{2}\right] \cdot 4 \mathrm{Cl}$ was recorded at -3.00 to $+3.00 \mathrm{~V}(v s \mathrm{Ag} / \mathrm{AgCl}$ ) with a scan rate of $100 \mathrm{mV} / \mathrm{s}$ in $\mathrm{DMF}$ solution at room temperature. We note one oxidation and two reduction pics and two oxidation (Figure 5). The cathodic wave shows two distinct reductive peaks at ca. $-0.9 \mathrm{v}$ and $-1.3 \mathrm{~V}(\Delta \mathrm{E}=0.4 \mathrm{~V})$ which correspond to two electrons charge

\section{Complex 1}

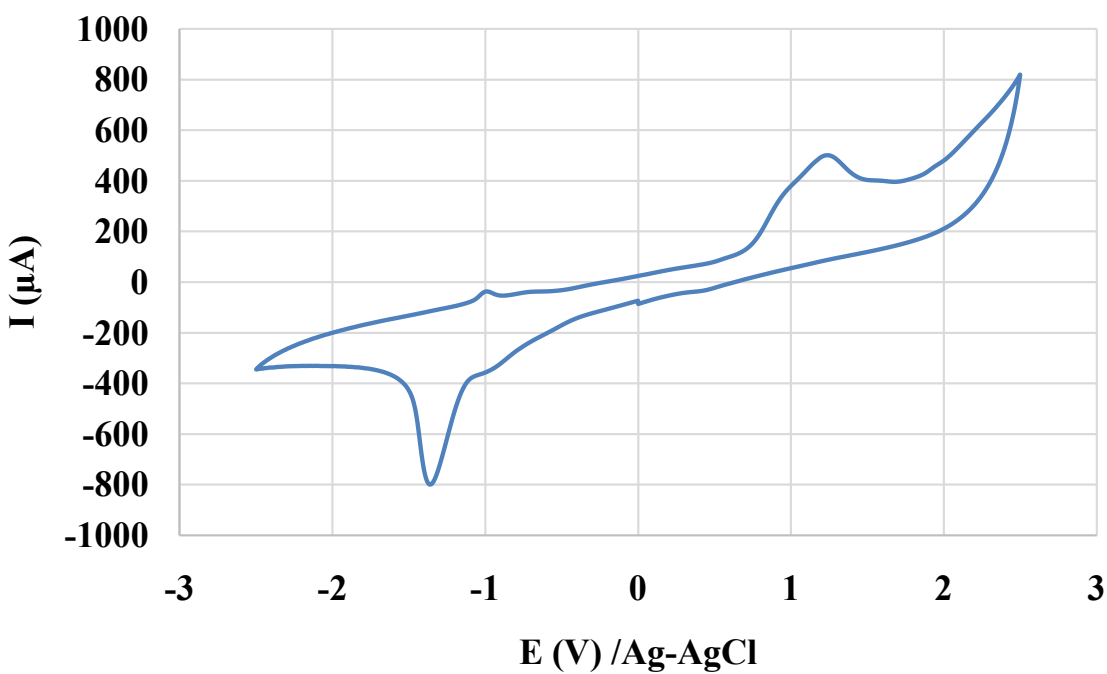

Figure 5. Cyclic Votammograms of the complex in $\mathrm{CH}_{3} \mathrm{CN}$ containing $0.1 \mathrm{M}\left[\mathrm{NBu}_{4}\right] \cdot\left[\mathrm{PF}_{6}\right]$ Working electrode: a $5 \mathrm{~mm}$ diameter of graphitecarbon electrode, scan rate: $100 \mathrm{~m} \cdot \mathrm{Vs}^{-1}$. 


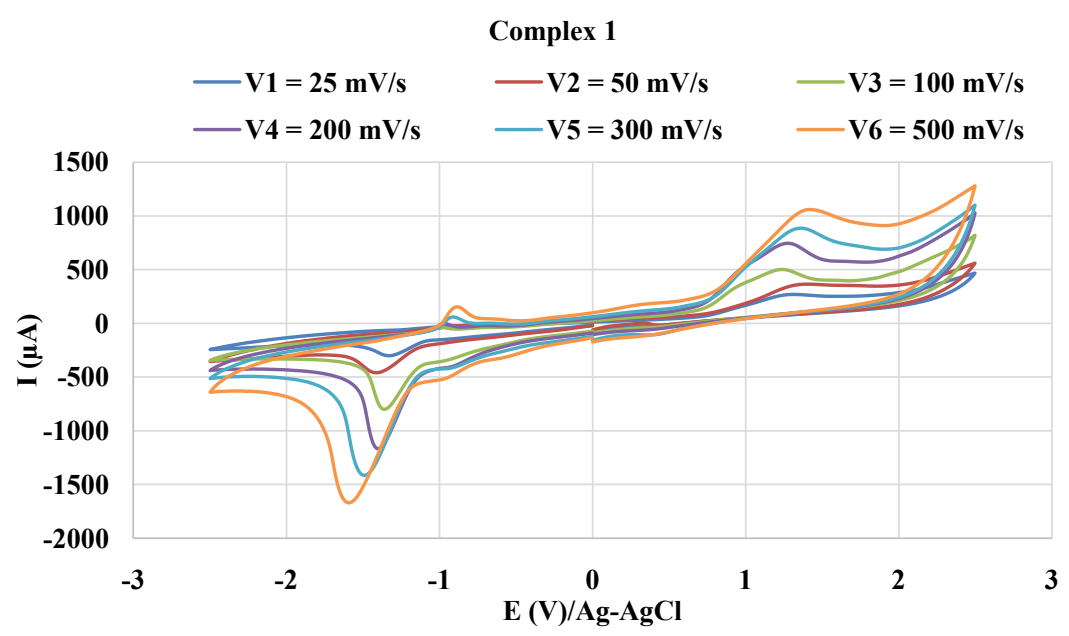

Figure 6. Cyclic Votammograms of the complex in $\mathrm{CH}_{3} \mathrm{CN}$ containing $0.1 \mathrm{M}$ [NBu4].[PF6] Scan rate: $25,150,100,200,300$ and $500 \mathrm{mVs}^{-1}$. Working electrode: a $2 \mathrm{~mm}$ diameter of graphite carbon electrode.

transfer process $\mathrm{Mn}(\mathrm{II}) \mathrm{Mn}(\mathrm{II}) \rightarrow \mathrm{Mn}(\mathrm{II}) \mathrm{Mn}(\mathrm{I})$ and $\mathrm{Mn}(\mathrm{II}) \mathrm{Mn}(\mathrm{I}) \rightarrow \mathrm{Mn}(\mathrm{I}) \mathrm{Mn}(\mathrm{I})$. The anodic wave shows two oxidative peaks -1.00 and $+1.2 \mathrm{~V}$ corresponding to the reversible process $\mathrm{Mn}(\mathrm{I}) \mathrm{Mn}(\mathrm{I}) \rightarrow \mathrm{Mn}(\mathrm{II}) \mathrm{Mn}(\mathrm{I})$ and $\mathrm{Mn}(\mathrm{II}) \mathrm{Mn}(\mathrm{I}) \rightarrow \mathrm{Mn}(\mathrm{II}) \mathrm{Mn}(\mathrm{II})$. A reversible transition $\mathrm{Mn}(\mathrm{II}) \rightarrow \mathrm{Mn}(\mathrm{I})$ had already been observed for a $\mathrm{Mn}(\mathrm{II})$ complex in acetonitrile media [49]. By varying the scans speed the intensities of all the peaks increase with the scanning speed (Figure 6).

\section{Conclusion}

We describe here one seven coordinated manganese (II) complexes of the tetradentate ligand 1-(1-(pyridin-2-yl)ethylidene)carbonohydrazide and one seven coordinated cobalt(II) of the tridentate 1-(pyridin-2-ylmethylene)carbonohydrazide. The single crystal structure of the Mn(II) complex 1 as well as of the Co(II) complex $\mathbf{2}$ has revealed a distorted pentagonal-bipyramidalgeometry. The equatorial plane in complex 1 is occupied by $\mathrm{N}_{2} \mathrm{O}$ and $\mathrm{NO}$ from two tetradentate ligand molecules acting as bridges between two $\mathrm{Mn}$ (II) ions. The axial positions are occupied by two coordinated water molecules. In the complex 2 , the equatorial plane of the bipyramid is occupied by the tridentate $\mathrm{N}_{2} \mathrm{O}$ ligand and two oxygen atoms from the coordinated nitrate anion which acts in bidentate chelating fashion, the two apical positions being occupied by two coordinated water molecules. The cyclic voltammetry studies in $\mathrm{CH}_{3} \mathrm{CN}$ show that the manganese (II) complex 2 shows two electrons charge transfer process.

\section{Acknowledgements}

The authors thank the FONDATION SONATEL for his financial support http://fondationsonatel.sn/.

\section{Supporting Information}

CCDC-1944387 and 1944386 contains the supplementary crystallographic data 
for this paper. These data can be obtained free of charge via

https://www.ccdc.cam.ac.uk/structures/, or by e-mailing

data_request@ccdc.cam.ac.uk, or by contacting The Cambridge Crystallographic

Data Centre, 12 Union Road, Cambridge CB2 1EZ, UK; fax: +44(0)1223-336033.

\section{Conflicts of Interest}

The authors declare no conflicts of interest regarding the publication of this paper.

\section{References}

[1] Ghosh, M., Layek, M., Fleck, M., Saha, R. and Bandyopadhyay, D. (2015) Synthesis, Crystal Structure and Antibacterial Activities of Mixed Ligand Copper(II) and Cobalt(II) Complexes of a NNS Schiff Base. Polyhedron, 85, 312-319. https://doi.org/10.1016/j.poly.2014.08.014

[2] Khorshidifard, M., Rudbari, H.A., Kazemi-Delikani, Z., Mirkhani, V. and Azadbakht, R. (2015) Synthesis, Characterization and X-Ray Crystal Structures of Vanadium(IV), Cobalt(III), Copper(II) and Zinc(II) Complexes Derived from an Asymmetric Bidentate Schiff-Base Ligand at Ambient Temperature. Journal of Molecular Structure, 1081, 494-505. https://doi.org/10.1016/j.molstruc.2014.10.071

[3] Gorczyński, A., Zaranek, M., Witomska, S., Bocian, A., Stefankiewicz, A.R., Kubicki, M., Patroniak, V. and Pawluć, P. (2016) The Cobalt(II) Complex of a New Tridentate Schiff-Base Ligand as a Catalyst for Hydrosilylation of Olefins. Catalysis Communications, 78, 71-74. https://doi.org/10.1016/j.catcom.2016.02.009

[4] Jing, C., Wang, C., Yan, K., Zhao, K., Sheng, G., Qu, D., Niu, F., Zhu, H. and You, Z. (2016) Synthesis, Structures and Urease Inhibitory Activity of Cobalt(III) Complexes with Schiff Bases. Bioorganic \& Medicinal Chemistry, 24, 270-276. https://doi.org/10.1016/j.bmc.2015.12.013

[5] Pogány, L., Moncol, J., Gál, M., Šalitroš, I. and Boča, R. (2017) Four Cobalt(III) Schiff Base Complexes-Structural, Spectroscopic and Electrochemical Studies. Inorganica Chimica Acta, 462, 23-29. https://doi.org/10.1016/j.ica.2017.03.001

[6] Wang, X.-W. and Zheng, Y.-Q. (2007) A Dinuclear Copper(II) Complex and a Zigzag Chain Iron(II) Polymer Based on the 4-Antipyrine Derived Schiff Base Ligands: The Hydroxylation and Redox Occurred under the Solvothermal Conditions. Inorganic Chemistry Communications, 10, 709-712. https://doi.org/10.1016/j.inoche.2007.03.008

[7] Zhang, E., Wei, Y., Huang, F., Yu, Q., Bian, H., Liang, H. and Lei, F. (2018) Synthesis, Crystal Structure and Bioactivity of Manganese Complexes with Asymmetric Chiral Schiff Base. Journal of Molecular Structure, 1155, 320-329. https://doi.org/10.1016/j.molstruc.2017.11.017

[8] Soliman, S.M., El-Faham, A., Elsilk, S.E. and Farooq, M. (2018) Two Heptacoordinated Manganese(II) Complexes of Giant Pentadentate s-Triazine Bis-Schiff Base Ligand: Synthesis, Crystal Structure, Biological and DFT Studies. Inorganica Chimica Acta, 479, 275-285. https://doi.org/10.1016/j.ica.2018.04.043

[9] Rathi, S., Maji, A., Singh, U.P. and Ghosh, K. (2019) Manganese (II) Complexes of Tridentate Ligands Having NNN Donors: Structure, DFT Calculations, Superoxide Dismutase, DNA Interaction, Nuclease and Protease Activity Studies. Inorganica Chimica Acta, 486, 261-273. https://doi.org/10.1016/j.ica.2018.09.081

[10] Sousa, J., Oliveira, D.R., Lomonaco, D., Correia, A.N., Sousa, C.P., Neto, P.L., Paulo, 
T.F., Mazzetto, S.E., Clemente, C.S. and Mele, G. (2019) Structural, Photophysical and Electrochemical Properties of a Novel Cardanol-Based Salophen Ligand and Its $\mathrm{Mn}$ (II) Complex. Journal of Molecular Structure, 1181, 279-286.

https://doi.org/10.1016/j.molstruc.2018.12.111

[11] Gorczyński, A., Pakulski, D., Szymańska, M., Kubicki, M., Bułat, K., Łuczak, T. and Patroniak, V. (2016) Electrochemical Deposition of the New Manganese(II) SchiffBase Complex on a Gold Template and Its Application for Dopamine Sensing in the Presence of Interfering Biogenic Compounds. Talanta, 149, 347-355.

https://doi.org/10.1016/j.talanta.2015.11.050

[12] Egekenze, R.N., Gultneh, Y. and Butcher, R. (2018) Mn(III) and Mn(II) Complexes of Tridentate Schiff Base Ligands; Synthesis, Characterization, Structure, Electrochemistry and Catalytic Activity. Inorganica Chimica Acta, 478, 232-242.

https://doi.org/10.1016/j.ica.2018.01.027

[13] Abdel-Rahman, L.H., Abu-Dief, A.M., Adam, M.S.S. and Hamdan, S.K. (2016) Some New Nano-Sized Mononuclear Cu(II) Schiff Base Complexes: Design, Characterization, Molecular Modeling and Catalytic Potentials in Benzyl Alcohol Oxidation. Catalysis Letters, 146, 1373-1396.

https://doi.org/10.1007/s10562-016-1755-0

[14] Al-Saeedi, S.I., Abdel-Rahman, L.H., Abu-Dief, A.M., Abdel-Fatah, S.M., Alotaibi, T.M., Alsalme, A.M. and Nafady, A. (2018) Catalytic Oxidation of Benzyl Alcohol Using Nanosized $\mathrm{Cu} / \mathrm{Ni}$ Schiff-Base Complexes and Their Metal Oxide Nanoparticles, Catalysts, 8, 452. https://doi.org/10.3390/catal8100452

[15] Zhou, J.-L., Guo, L., Yu, W.-D., Zhang, Z.-H., Wang, Y. and Yan, J. (2019) Impact of Ligand Rotation: Synthesis, Crystal Structures and Third-Order Nonlinear Optical Properties of $\mathrm{Mn}(\mathrm{II}), \mathrm{Cu}(\mathrm{II})$ and $\mathrm{Ni}(\mathrm{II})$ Complexes with 5-diethylamino-2((4-(phenyldiazenyl) phenylimino) methyl) Phenol. Inorganic Chemistry Communications, 99, 189-194. https://doi.org/10.1016/j.inoche.2018.11.023

[16] Choubey, S., Roy, S., Bhar, K., Ghosh, R., Mitra, P., Lin, C.-H., Ribas, J. and Ghosh, B.K. (2013) Syntheses, Structures, and Magnetic Properties of Terephthalato Bridged Dinuclear Copper(II) and Manganese(II) Complexes with a Tetradentate N-Donor Schiff Base. Polyhedron, 55, 1-9. https://doi.org/10.1016/j.poly.2013.02.062

[17] Elshafaie, A., Abdel-Rahman, L.H., Abu-Dief, A.M., Hamdan, S.K., Ahmed, A.M. and Ibrahim, E.M.M. (2018) Electric, Thermoelectric and Magnetic Properties of Nickel(II) Imine Nanocomplexes. NANO: Brief Reports and Reviews, 13, Article ID: 1850074. https://doi.org/10.1142/S1793292018500741

[18] Raju, V., Kumar, R.S., Tharakeswar, Y. and Kumar, S.K.A. (2019) A Multifunctional Schiff-Base as Chromogenic Chemosensor for $\mathrm{Mn}^{2+}$ and Fluorescent Chemosensor for $\mathrm{Zn}^{2+}$ in Semi-Aqueous Environment. Inorganica Chimica Acta, 493, 49-56. https://doi.org/10.1016/j.ica.2019.04.053

[19] Abu-Dief, A.M., Díaz-Torres, R., Sañudo, E.C., Abdel-Rahman, L.H. and Aliaga-Alcalde, N. (2013) Novel Sandwich Triple-Decker Dinuclear NdIII-(bis-N,N'-pbromo-salicylideneamine-1,2-diaminobenzene) Complex. Polyhedron, 64, 203-208. https://doi.org/10.1016/j.poly.2013.04.010

[20] Li, H., Xi, D., Niu, Y., Wang, C., Xu, F., Liang, L. and Xu, P. (2019) Design, Synthesis and Biological Evaluation of Cobalt(II)-Schiff Base Complexes as ATP-Noncompetitive MEK1 Inhibitors. Journal of Inorganic Biochemistry, 195, 174-181. https://doi.org/10.1016/j.jinorgbio.2019.03.022

[21] Abdel-Rahmana, L.H., Abu-Dief, A.M., Aboelez, M.O. and Abdel-Mawgoud, A.A.H. 
(2017) DNA Interaction, Antimicrobial, Anticancer Activities and Molecular Docking Study of Some New VO(II), Cr(III), Mn(II) and Ni(II) Mononuclear Chelates Encompassing Quaridentate Imine Ligand. Journal of Photochemistry \& Photobiology, B: Biology, 170, 271-285. https://doi.org/10.1016/j.jphotobiol.2017.04.003

[22] Abdel-Rahman, L.H., Abu-Dief, A.M., Shehata, M.R., Atlam, F.M. and Abdel-Mawgoud, A.A.H. (2019) Some New $\mathrm{Ag}(\mathrm{I}), \mathrm{VO}(\mathrm{II})$ and $\mathrm{Pd}(\mathrm{II})$ Chelates Incorporating Tridentate Imine Ligand: Design, Synthesis, Structure Elucidation, Density Functional Theory Calculations for DNA Interaction, Antimicrobial and Anticancer Activities and Molecular Docking Studies. Applied Organometallic Chemistry, 33, e4699. https://doi.org/10.1002/aoc.4699

[23] Pordea, A., Mathis, D. and Ward, T.R. (2009) Incorporation of Biotinylated Manganese-Salen Complexes into Streptavidin: New Artificial Metalloenzymes for Enantioselective Sulfoxidation. Journal of Organometallic Chemistry, 694, 930-936. https://doi.org/10.1016/j.jorganchem.2008.11.023

[24] Rondot, L., Girgenti, E., Oddon, F., Marchi-Delapierre, C., Jorge-Robin, A. and Ménage, S. (2016) Catalysis without a Headache: Modification of Ibuprofen for the Design of Artificial Metalloenzyme for Sulfide Oxidation. Journal of Molecular Catalysis A: Chemical, 416, 20-28. https://doi.org/10.1016/j.molcata.2016.02.015

[25] McKee, V. (1993) Macrocyclic Complexes as Models for Nonporphine Metalloproteins. Advances in Inorganic Chemistry, 40, 323-410. https://doi.org/10.1016/S0898-8838(08)60186-5

[26] Horrocks, W.D. and Burlone, D.A. (1979) Metalloprotein Models, Location of the Magnetic Axes in Low-Symmetry Complexes. Single Crystal Electron Paramagnetic Resonance, Magnetic Susceptibility Anisotropy, and Angular Overlap Ligand Field Calculations on a Complex Containing the Distorted Tetrahedral $\mathrm{Co}^{\mathrm{II}} \mathrm{N}_{2} \mathrm{O}_{2}$ Coordination Unit, Bis(N-isopropylsalicyclaldiminato)cobalt(II). Inorganica Chimica Acta, 35, 165-175. https://doi.org/10.1016/S0020-1693(00)93435-2

[27] Bhar, K., Sutradhar, D., Choubey, S., Ghosh, R., Lin, C.-H., Ribas, J. and Ghosh, B.K. (2013) Hexa- and Hepta-Coordinated Manganese(II) Dicyanamide Complexes Containing a Tetradentate N-Donor Schiff Base: Syntheses, Composition Tailored Architectures and Magnetic Properties. Journal of Molecular Structure, 1051, $107-$ 114. https://doi.org/10.1016/j.molstruc.2013.07.029

[28] Martinez-Bulit, P., Garza-Ortíz, A., Mijangos, E., Barrón-Sosa, L., Sánchez-Bartéz, F., Gracia-Mora, I., Flores-Parra, A., Contreras, R., Reedijk, J. and Barba-Behrens, N. (2015) 2,6-Bis(2,6-diethylphenyliminomethyl)pyridine Coordination Compounds with Cobalt(II), Nickel(II), Copper(II), and Zinc(II): Synthesis, Spectroscopic Characterization, X-Ray Study and in Vitro Cytotoxicity. Journal of Inorganic Biochemistry, 142, 1-7. https://doi.org/10.1016/j.jinorgbio.2014.09.007

[29] Gökçe, C., Dilek, N. and Gup, R. (2015) Seven Coordinated Cobalt(II) Complexes with 2,6-Diacetylpyridine Bis(4-acylhydrazone) Ligands: Synthesis, Characterization, DNA-Binding and Nuclease Activity. Inorganica Chimica Acta, 432, 213-220. https://doi.org/10.1016/j.ica.2015.03.040

[30] Baffert, C., Collomb, M.-N., Deronzier, A., Kjærgaard-Knudsen, S., Latour, J.-M., Lund, K.H., McKenzie, C.J., Mortensen, M., Nielsen, L.P. and Thorup, N. (2003) Biologically Relevant Mono- and Di-Nuclear Manganese II/III/IV Complexes of Mononegative Pentadentate Ligands. Dalton Transaction, 9, 1765-1772. https://doi.org/10.1039/b300823a

[31] Waldo, G.S. and Penner-Hahn, J.E. (1995) Mechanism of Manganese Catalase Peroxide Disproportionation: Determination of Manganese Oxidation States during Turnover. Biochemistry, 34, 1507-1512. https://doi.org/10.1021/bi00005a006 
[32] Zahran, Z.N., Chooback, L., Copeland, D.M., West, A.H. and Richter-Addo, G.B. (2008) Crystal Structures of Manganese- and Cobalt-Substituted Myoglobin in Complex with NO and Nitrite Reveal Unusual Ligand Conformations. Journal of Inorganic Biochemistry, 102, 216-233. https://doi.org/10.1016/j.jinorgbio.2007.08.002

[33] Türkoğlu, S. and Özer, İ. (1992) Possible Involvement of Manganese in the Catalytic Mechanism of Bovine Liver Arginase. International Journal of Biochemistry, 24, 937-939. https://doi.org/10.1016/0020-711X(92)90100-F

[34] Shiga, T. and Oshio, H. (2007) Syntheses, Structures and Magnetic Properties of Mixed-Valence Pentanuclear $\left[\mathrm{Mn}_{3}{ }^{\mathrm{II}} \mathrm{Mn}_{2}{ }^{\mathrm{II}}\right]$ and Hexanuclear $\left[\mathrm{Co}_{4}{ }^{\mathrm{II}} \mathrm{Co}_{2}{ }^{\mathrm{III}}\right]$ Complexes Derived from 3-Formylsalicylic Acid. Polyhedron, 26, 1881-1884.

https://doi.org/10.1016/j.poly.2006.09.026

[35] Nayak, M., Hazra, S., Lemoine, P., Koner, R., Lucas, C.R. and Mohanta, S. (2008) Self-Assembled $[2 \times 1+1 \times 2]$ Heterotetranuclear $\mathrm{Cu}_{3}{ }_{3} \mathrm{Mn}^{\mathrm{II}} / \mathrm{Cu}_{3}{ }_{3} \mathrm{Co}^{\mathrm{II}}$ and $[2 \times 2+1 \times 3]$ Heptanuclear $\mathrm{Cu}_{7}{ }_{7}$ Compounds Derived from N,N'-o-phenylenebis(3-ethoxysalicylaldimine): Structures and Magnetic Properties. Polyhedron, 27, 1201-1213. https://doi.org/10.1016/j.poly.2007.12.010

[36] Bar, A.K., Pichon, C. and Sutter, J.-P. (2016) Magnetic Anisotropy in Two- to Eight-Coordinated Transition-Metal Complexes: Recent Developments in Molecular Magnetism. Coordination Chemistry Reviews, 308, 346-380. https://doi.org/10.1016/j.ccr.2015.06.013

[37] Dieng, M., Diouf, O., Gaye, M., Sall, A.S., Pérez-Lourido, P., Valencia, L., Caneschi, A. and Sorace, L. (2013) Polynuclear Nickel(II) Complexes with Salicylaldimine Derivative Ligands. Inorganica Chimica Acta, 394, 741-746. https://doi.org/10.1016/j.ica.2012.09.037

[38] Sow, M.M., Diouf, O., Gaye, M., Sall, A.S., Pérez-Lourido, P., Valencia-Matarranz, L., Castro, G., Caneschi, A. and Sorace, L. (2013) Synthesis, Spectral Characterization and X-Ray Crystal Structure of Fe(III) and Co(III) Complexes with an Acyclic Schiff Base Ligand. Inorganica Chimica Acta, 406, 171-175. https://doi.org/10.1016/j.ica.2013.07.018

[39] Sow, M.M., Diouf, O., Gaye, M., Salam-Sall, A., Castro, G., Pérez-Lourido, P., Valencia, L., Caneschi, A. and Sorace, L. (2013) Sheets of Tetranuclear Ni(II) [2 $\times 2]$ Square Grids Structure with Infinite Orthogonal Two-Dimensional Water-Chlorine Chains. Crystal Growth \& Design, 13, 4172-4176. https://doi.org/10.1021/cg400885f

[40] Sheldrick, G.M. (1997) SHELXTL 97. Program for the Refinement of Crystal Structures. University of Göttingen, Göttingen.

[41] Farrugia, L.J. (1997) It ORTEP-3 for Windows-A Version of It ORTEP-III with a Graphical User Interface (GUI). Journal of Applied Crystallography, 30, 565. https://doi.org/10.1107/S0021889897003117

[42] Singh, A.K., Pandey, O.P. and Sengupta, S.K. (2013) Synthesis, Spectral and Antimicrobial Activity of $\mathrm{Zn}$ (II) Complexes with Schiff Bases Derived from 2-Hydrazino5-[Substituted phenyl]-1,3,4-Thiadiazole and Benzaldehyde/2-Hydroxyacetophenone/Indoline-2,3-Dione. Spectrochimica Acta Part A: Molecular and Biomolecular Spectroscopy, 113, 393-399. https://doi.org/10.1016/j.saa.2013.04.045

[43] Abdel-Rahman, L.H., Abu-Dief, A.M., El-Khatib, R.M. and Abdel-Fatah, S.M. (2016) Sonochemical Synthesis, DNA Binding, Antimicrobial Evaluation and in Vitro Anticancer Activity of Three New Nano-Sized $\mathrm{Cu}$ (II), Co(II) and Ni(II) Chelates Based on Tridentate NOO Imine Ligands as Precursors for Metal Oxides. Journal of Photochemistry and Photobiology B: Biology, 162, 298-308. 
https://doi.org/10.1016/j.jphotobiol.2016.06.052

[44] Abdel-Rahman, L.H., Ismail, N.M., Ismael, M., Abu-Dief, A.M. and Ahmed, E.A. (2017) Synthesis, Characterization, DFT Calculations and Biological Studies of $\mathrm{Mn}(\mathrm{II}), \mathrm{Fe}(\mathrm{II}), \mathrm{Co}(\mathrm{II})$ and $\mathrm{Cd}(\mathrm{II})$ Complexes Based on a Tetradentate ONNO Donor Schiff Base Ligand. Journal of Molecular Structure, 1134, 851-862. https://doi.org/10.1016/j.molstruc.2017.01.036

[45] Kumar, D.S. and Alexander, V. (1995) Macrocyclic Complexes of Lanthanides in Identical Ligand Frameworks Part 1. Synthesis of Lanthanide(III) and Yttrium(III) Complexes of an 18-Membered Dioxatetraaza Macrocycle. Inorganica Chimica Acta, 238, 63-71. https://doi.org/10.1016/0020-1693(95)04687-5

[46] Geary, W.J. (1971) The Use of Conductivity Measurements in Organic Solvents for the Characterisation of Coordination Compounds. Coordination Chemistry Reviews, 7, 81-122. https://doi.org/10.1016/S0010-8545(00)80009-0

[47] Sarr, M., Diop, M., Thiam, E.I., Barry, A.H., Gaye, M. and Retailleau, P. (2018) Crystal Structure of Aquachlorido(nitrato- $\left.\kappa^{2} \mathrm{O}, \mathrm{O}^{\prime}\right)[1-($ pyridin-2-yl- $\kappa \mathrm{N})-2$-(pyridin2-ylmethylidene- $\kappa \mathrm{N}$ )hydrazine- $\kappa \mathrm{N}^{2}$ ]manganase(II). Acta Crystallographica Section E: Crystallographic Communications, 74, 450-453. https://doi.org/10.1107/S2056989018003493

[48] Schleife, F., Rodenstein, A., Kirmse, R. and Kersting, B. (2011) Seven-Coordinate $\mathrm{Mn}$ (II) and Co(II) Complexes of the Pentadentate Ligand 2,6-Diacetyl-4-Carboxymethyl-Pyridine Bis(benzoylhydrazone): Synthesis, Crystal Structure and Magnetic Properties. Inorganica Chimica Acta, 374, 521-527. https://doi.org/10.1016/j.ica.2011.02.064

[49] Compton, R.G., Barghout, R., Eklund, J.C. and Fisher, A.C. (1993) Organometallic Photoelectrochemistry: Oxidation of fac-Tricarbonylchloro[bis(diphenylphosphino) methane] Manganese(I). Journal of Physical Chemistry, 97, 1661-1664.

https://doi.org/10.1021/j100110a031 